\title{
The Deductibility by Individuals of Capital Losses under the Federal Income Tax
}

\author{
Alvin C. Warren, Jr.†
}

The federal income tax consequences for individuals who realize capital losses have undergone a bewildering number of changes since the adoption of the sixteenth amendment. Originally denied deductibility from ordinary income, ${ }^{1}$ capital losses were for a short period fully deductible; ${ }^{2}$ since 1924 they have been only partially deductible. The limitations imposed since 1924 include an offset against capital gains only, a maximum tax credit, a sliding scale of recognition based on the period held, and, currently, reduction of no more than $\$ 1,000$ of ordinary income a year with two dollars of net long-term capital loss required for each dollar of ordinary income reduced..$^{3}$ Although Congress

† Associate Professor of Law, University of Connecticut School of Law.

1 The first income tax after the adoption of the sixteenth amendment denied a deduction to capital losses while capital gains were taxed in full; noncasualty losses were deductible only if "incurred in trade." Act of Oct. 3, 1913, ch. 16, § Ir(B), 38 Stat. 167. Ambiguity in the legislative history regarding inclusion and deduction of capital gains and losses was resolved in the Government's favor. See Merchants' Loan \&e Trust Co. v. Smietanka, 255 U.S. 509 (1921); Mente v. Eisner, 266 F. 161, 162 (2d Cir. 1920); 50 Cong. REc. 506, 513, 3849-50 (1913).

2 In 1916, losses were allowed to the extent of gains, Act of Sept. 8, 1916, ch. 463, § 5(a) fifth, 39 Stat. 759, while the Revenue Act of 1918 permitted unlimited loss deductions, Revenue Act of 1918, ch. 18, \& 214(a)(5), 40 Stat. 1067, treatment that was continued even after capital gains were granted preferential taxation in 1921. Revenue Act of 1921, ch. 186, $\S \S 206,214(\mathrm{a})(5), 42$ Stat. 232, 240.

3 In 1924 Congress began again to limit deductibility by providing a maximum tax credit for capital losses equal to the maximum tax applied to capital gains. Act of June 2, 1924, ch. 234, \& 208(c), 43 Stat, 256. In 1932 losses on stocks and bonds held two years or less were limited to such gains, Revenue Act of 1932, ch. 209, § 23r, 47 Stat. 183, subject to a one year carryover that was repealed before it could take effect. See note 77 infra. The Revenue Act of 1934 brought a more significant shift in the taxation of capital gains and losses: thereafter gains and losses were recognized in accordance with a scale that declined in five steps from 100 percent to 30 percent depending on the period held. Losses so recognized were deductible from gains plus $\$ 2,000$ of other income. Revenue Act of 1934, ch. $277, \S 117,48$ Stat. 714 . The number of steps in the scale was later reduced to three and a distinction drawn at eighteen months between short-term and long-term gains and losses. Revenue Act of 1938, ch. 289, § 117, 52 Stat. 500. Short-term losses were made deductible from short-term gains only, with any excess loss carried forward. Long-term gains and losses were again subject to a maximum tax and tax credit. $I d$.

The basic provisions in effect today were introduced in the Revenue Act of 1942, ch. 619, $\S 150,56$ Stat. 843. Short-term and long-term gains were distinguished on the basis of a six-month holding period. Fifty percent of long-term gains and losses were included in 
has modified the statutory treatment of capital losses more often than that of capital gains, there has been surprisingly little commentary on the deductibility of such losses, ${ }^{4}$ especially when compared to the staggering controversy generated by the partial inclusion of capital gains in taxable income. 5

This article discusses the appropriate tax treatment for capital losses realized by individual taxpayers, given the current preferential treatment of capital gains-the 50 percent deduction ${ }^{6}$ and alternative tax 7 for an excess of net long-term capital gain over net short-term capital loss, the netting scheme, ${ }^{8}$ and the stepped-up basis for appreciated assets at death. ${ }^{9}$ Corporate deductions, which raise unique problems, are not dealt with here, nor is an attempt made to extend the proposals advanced to the special computations mandated for fiduciary

income while an alternative tax was provided for gains. Capital losses were deductible up to the amount of capital gains plus $\$ 1,000$ of other income and a five-year carryover was permitted for short-term and long-term losses. $x d$.

The modifications of the last thirty years have been more in the nature of technical refinement than fundamental change. The 50 percent recognition of long-term gains and losses has been dropped in favor of a 50 percent deduction of the excess of net long-term capital gain over net short-term capital loss in order to end an anomalous two-for-one offset whereby $\$ 5,000$ of short-term losses could offset $\$ 10,000$ of long-term gains. Revenue Act of 1951, ch. 521, § 322(a)(2), 65 Stat. 499. An unlimited carryover for capital losses has been added, with losses retaining their character as long-term or short-term. Revenue Act of 1964, § 230, 78 Stat. 99. Finally, a dollar of net long-term capital loss now offsets only fifty cents of ordinary income within the $\$ 1,000$ limit. INT. REv. CoDE of 1954, \$§ 1211-12. This change was designed to eliminate a new two-for-one offset, introduced by the corrective of the 1951 Act, whereby each dollar of an excess of net long-term capital loss over net short-term capital gain offset a dollar of ordinary income while only fifty cents of each dollar of an excess of net long-term capital loss over net short-term capital gain offset a dollar of ordinary income while only fifty cents of each dollar of an excess of net long-term capital gain over net short-term capital loss was included in taxable income. See also Wells, Legislative History of Treatment of Capital Gains under the Federal Income Tax, 1913-1948, 2 NAT'L TAx J. 12 (1949).

4 The principal commentaries are: $M$. David, Alternative Approaches to Gaptral gains Taxation 140-43 (1968); L. Seltzer, The Nature and Tax Treatment of Capital Gains and Losses (1951); U.S. Treasury Dep't, Federal Income Tax Treatment of Capital GaINS AND Losses 59-69 (1951) [hereinafter cited as Treasury Dep'T STUdY]; Break, On the Deductibility of Capital Losses Under the Income Tax, 7 J. Finance 214 (1952).

5 Alternative treatments of capital gains suggested by commentators and foreign tax systems are catalogued in M. DAvid, supra note 4, at 109-208; R. MAglll, Taxable Income 115-21 (2d ed. 1945); R. MusGrave, Fiscal SYstems 195-99 (1969); L. SeLtzer, supra note 4, at 254-318; TREASURY DEP'T STUDY, supra note 4, at 101-04; Kohler, Report of Committee on Taxation of Capital Gains, 31 NAT'L TAX Ass'N CONF. Proceed. 806, 810-11 (1938); and Miller, Existing and Proposed Provisions of Law Regarding Capital Gains and Losses, 32 NAT'L TAX Ass'N CONF. Procked. 126 (1939).

6 Int. Rev. Code of 1954, $\$ 1202$.

7 Id. $\$ 1201$.

8 Id. $\S \S 1201-23$.

9 Id. $\S 1014$. 
returns. Rather, by focusing on individual returns, where the bulk of capital gains and losses are reported, ${ }^{10}$ this article attempts to develop a theoretically correct model for the treatment of capital losses. Some might argue the sport not worth the candle on the ground that the current rules regarding capital gains and losses are already far too complicated for individuals preparing schedule D's. While such administrative considerations must be important in the formulation of tax policy, they are but one factor and do not eliminate the need for inquiry into fundamental questions of tax fairness.

That inquiry here proceeds by examining arguments for and against full deductibility in order to isolate criteria for suitable treatment of losses. The current statutory provisions and proposals for reform are then examined in light of these criteria.

\section{The Gase for Full Deductibility}

\section{A. The Net Income Concept}

Net income consists of net annual receipts above the maintenance of capital; ${ }^{11}$ unless capital losses are deductible, therefore, the income tax becomes pro tanto a levy on capital. This statement of the theoretical basis for full deductibility is but a corollary of the Haig-Simons definition of income as consumption plus or minus any change in net worth. ${ }^{12}$ One need not be drawn into the debate over the comprehensive tax base, ${ }^{13}$ however, to accept the proposition that capital losses are negative income, just as capital gains are positive income.

All would agree that an equitable net income tax should recognize that if two otherwise similarly situated taxpayers, $A$ and $B$, have the same ordinary income from business, but $A$ has n. concurrent business losses while $B$ does, $A$ can command more goods and services than $B$ as a result of his transactions during the tax year. This difference between the net positions of the two taxpayers is reflected by permitting deduction of business losses from ordinary income in computing tax liability. Similarly, if $A$ and $B$ have the same amount of capital gains but only $B$ has sustained any capital losses, the net income concept requires that $B$ be permitted to deduct his losses from his gains so that the difference between the net positions of the two taxpayers is reflected in

10 M. DAvid, supra note 4, at 62-93.

11 Treasury Dep't Study, supra note 4, at 60. See also G. Conway, The Taxation of Capital Gains 189 (Studies of the Royal (Canadian) Commission on Taxation, No. 19) (1968); Twentieth Century Fund, Facing the Tax Problem 488 (1937).

12 H. Simons, Personar, Income TAXation 50 (1938).

13 See B. Bittker, C. Galvin, R. Musgrave, \& J. Pechman, A Comprehensive income TAX BASE? A DeBATE (1968). 
their tax bills. ${ }^{14}$ If neither $A$ nor $B$, both having an equal amount of capital gains, has experienced any capital losses, but $B$ has business losses, he should be permitted to deduct his business losses from the taxable income produced by his capital gains in order to reduce his tax liability below that of $A$, who suffered no losses.

Suppose now that two taxpayers each have ordinary business income of $\$ 10,000 ; B$ has a capital loss of $\$ 5,000$ while $A$ has no losses of any kind. $B$ has acquired the power to command $\$ 5,000$ in additional goods and services while $A$ can command $\$ 10,000$ more than formerly. Unless there is reason to believe that $B$ 's $\$ 5,000$ loss is unworthy of recognition solely because it is a capital rather than a business loss, he should be permitted the deduction to reflect the fact that he has not achieved as great a net economic gain as the taxpayer who sustained no losses. Indeed, if he were not permitted the deduction, either currently or as a carryover, only half of his tax could truly be said to fall on his "net" income. The other half would be tantamount to a levy on $\$ 5,000$ of his capital.

The argument for full deductibility of capital losses as a matter of equity - treating like cases alike-was made before the Senate Finance Committee as early as 1916, along with the assertion that this had been the intent of Congress when the income tax was first enacted in 1913.15 Two years later, when Congress expressly embraced full deductibility, the chairman of the House Ways and Means Committee defended the measure as a matter of equity:

Under the present act a loss to the taxpayer can only be deducted if it is connected with the transactions of the business, while a casual loss on th. , outside cannot be deducted. To illustrate, suppose I am a player of the stock market, and that is my business. Suppose I lose $\$ 50,000$. I can deduct that from my total year's earnings. . . . [B]ut if I am a merchant, a farmer, or a lawyer, and happen to see

14 Because capital gains and losses may have accrued in different years, it cannot necessarily be said that $A$ can command $\$ 5,000$ more in goods and services than $B$ as a result of his transactions during the tax year. That divergence from the ordinary income case, however, follows from the intersection of the annual accounting and realization conventions of income taxation; it does not weaken the conclusion that $A$ is $\$ 5,000$ ahead of $B$ in terms of realized power to purchase goods and services. (This and examples in the text assume that the postulated capital losses were incurred in transactions entered into for profit.)

15 Memorandum submitted by Robert $R$. Reed, Counsel on behalf of the Investment Bankers Association, Increase of Revenue, Briefs and Statements filed with the Senate Finance Comm. on H.R. 16763, 64th Cong., 1st Sess. 58-59 (1916); see Statement of Robert Reed, in Hearings on the Revenue Act of 1918 Before the House Comm. on Ways and Means, 65th Cong., 2d Sess. 242-45 (1918); Major, The Revised Federal Income Tax Law, 2 Cornell L.Q. 73, 78 (1917); Note, 19 Mich. L. Rev. 103, 104 (1920). 
something in the paper which makes me think I can make a big sum of money, and then I go out and buy a future contract, and make a loss of $\$ 10,000$, I cannot deduct that from my income under the existing law or under the act of 1913. . . . Now, this bill permits all taxpayers to deduct their losses that are made in their business or outside of their business during the year. If I make $\$ 10,000$ in the practice of the law and lose $\$ 10,000$ on the stock market I can deduct it, because in the case I have supposed I would have no income left. ${ }^{16}$

Because Congress has, since 1924, refused to allow full deduction of capital losses, references in subsequent legislative history to the theoretical validity of unlimited deductions have necessarily been minimal. ${ }^{17}$ Among commentators, however, there is a fair amount of agreement that full deductibility is theoretically justified, but the expected revenue and avoidance effects of such a policy have led many of them to refrain from advocating it in practice. ${ }^{18}$

Moreover, there is a theoretical argument, made at one time with some vehemence, that capital losses and gains do not represent the same sort of reductions of, and additions to, income as do other changes in

1056 CoNG. REc. App. 678 (1918) (remarks of Mr. Kitchin). See also Statement of Mr. Thomas Garrett, Jr., in Hearings on the Revenue Act of 1918 Before the House Comm. on IVay's and Means, 65th Cong., 2d Sess. 858-62 (1918); Statement of Dr. Jak A. Schwarzman, id. at 282-83.

17 The most explicit recent reference-one sentence long-is found in a summary of the arguments for and against each provision of the Tax Reform Act of 1969. Staffs of Senate Comm. on Finance and Joint Comm. on Internal Revenue Taxation, in Hearings on the Tax Reform Act of 1969 Before the Senate Comm. on Finance, 91st Cong., 1st Sess. 95 (1969). Legislative references to the mandate of the net income concept have typically been relegated to the task of justifying exceptions to the developing general rule of nondeductibility in order to mitigate hardships for small taxpayers. See S. REP. No. 558, 73d Cong., 2d Sess. 12 (1934), 1939-1 Cum. Bull. (Part 2) 595; SubCOMm. of the House CoMm. on Ways and Means, Proposed Revision of the Revenue Laws, 75th Cong., 3d Sess. 32 (1938); Statement of Randolph E. Paul, Tax Advisor to the Secretary of the Treasury, in 2 Revenue Revision of 1942, Hearings Before the House Comm. on Ways and Means, 77th Cong., 2d Sess., 1611, 1635 (1942); President's 1963 Tax Message, in Hearings on the Revenue Act of 1963 Before the House Comm. on Ways and Means, 88th Cong., 1st Sess. 23-24 (1963); cf. S. REp. No. 1567, 75th Cong., 3d Sess. 6 (1938), 1939-1 CuM. BuLl. (Part 2) 783. The premise of such efforts, although often unarticulated, is that the hardship created by prohibiting deductions of capital losses from ordinary income is especially great for the smaller taxpayer who cannot mitigate the effect of loss limitations by offsetting against abundant capital gains.

I8 See R. Blough, The Federal Taxing Process 326 (1952); M. David, supra note 4, at 223-24; Royal. Commission on Taxation [U.K.] of Profits and Income, Final Report 30, 433 (1955) [U.K. CMD 9474]; TREASURX DEP'T STUDY, supra note 4, at 60-61; Colm, The Revenue Act of 1938, 5 Soc. RESEARCH 255, 257-59 (1938); Lowndes, The Taxation of Capital Gains and Losses Under the Federal Income Tax, 26 TExAs L. REv. 440, 460 (1948); Ramesh, Future of the Capital Gains Tax, 6 IND. Econ. J. 217, 219 (1958); Tudor, The Equitable Justification for the Capital Gains Tax, 34 TAxes 643, 645 (1956). 
wealth. ${ }^{10}$ Capital gains and losses are illusory, it is argued, to the extent that they represent changes only in the general price level due to inflationary or deflationary pressures. ${ }^{20}$ It is clear, however, that not all changes in the value of capital assets are attributable to changes in the value of money. If correction for the relationship between losses and the price level is thought to be important, therefore, it would be necessary to isolate the components of every change in value and measure their relative significance. This would require differentiating losses owing, for example, to poor management from losses that reflect a decline in the general price level -a task that would be administratively impossible.

In addition, even if the administrative problem could be overcome, it would be unfair to adjust only capital gains and losses for price level changes that also affected other items of income. ${ }^{21}$ While it would be discriminatory to apply a price deflator only to capital asset transactions, its application to all income would probably not be feasible; it might also be unwise to interfere with the stabilizing effect of the federal income tax by holding tax liability constant in a period of declining prices. ${ }^{22}$

Finally, adjustment of capital losses for price level changes would probably fail to win taxpayer acceptance because not all capital assets are affected equally by changes in the price level. Indeed, in a period of falling prices, a money value capital loss that fell short of the deflation would be a "real" gain. If the general price level halved, for example, a taxpayer whose $\$ 20,000$ securities dropped in value only to $\$ 15,000$ would have a money loss of $\$ 5,000$ on sale but a taxable gain of $\$ 5,000$. Similarly an increase in value that failed to keep pace with inflation would constitute a deductible loss. Thus, if the general price level doubled while the value of a taxpayer's securities increased from $\$ 20,000$ only to $\$ 30,000$, his $\$ 10,000$ money gain on sale would yield a deductible loss of $\$ 10,000$. Results so contrary to common understanding would be difficult for taxpayers to accept, and might substantially undermine

19 See Tax Instirute, Inc., Capital Gains Taxation 73-81 (1946).

20 Particularly good analyses of this problem can be found in L. SELTZER, supra note 4, at 98-103, and Break, supra note 4, at 219-22, on which the position taken in the text draws heavily. See also M. David, supra note 4, at 6, 48-49; TrEAsURY Dep'T STUdY, supra note 4, at 19-20; Blum, Handy Summary of the Capital Gains Arguments, 35 TAxes 247, 255-56 (1957).

21 For instance, despite the 1964-65 reduction in nominal tax rates, inflation actually raised real tax rates between 1954 and 1970, especially for taxpayers with low incomes or large families. See Goetz \& Weber, Intertemporal Changes in Real Federal Income Tax Rates, 1954-70, 24 NAT'L TAX J. 51 (1971).

22 See R. Goode, The Individul Income TAx 192-93 (1964). 
whatever belief they still have in the fairness of the capital gain and loss provisions.

Difficulties of administration, problems of equity and the confusion likely to result from its application thus lead to rejection of the argument that changes in the general price level make a dollar of capital loss worth less-and therefore less worthy of deductibility-than any other dollar of negative income. ${ }^{23}$

\section{B. Economic Incentives for Risk Taking.}

In addition to the theoretical argument based on the net income concept, the primary rationale for making capital losses fully deductible is in the economic incentive for risk taking it would provide. The securities industry has long complained that new capital ventures are made less attractive because the government insists upon having so large a share of capital gains and so small a share of the losses.24 Equity investment, particularly in new enterprises of greater than usual risk, is discouraged by the failure of the tax system to permit full deduction of losses. Yet the legislative history of loss limitations only occasionally manifests congressional recognition ${ }^{25}$ of the argument that taxpayers

23 A special case is sometimes made for the illusory nature of capital gains and losses where the change in value is caused by a change in interest rates. See TAX INSTITUTE, INc., supra note 19 , at 71-83. Assume that $A$, who has $\$ 100,000$ to invest, purchases a fixed in: come asset that yields 5 percent, or $\$ 5,000$. Assuming the general price level remains constant, will a rise in the interest rate on $A$ 's asset cause him to incur a real loss? If the interest rate increases to 10 percent, the value of his asset will drop to $\$ 50,000$. Sale of the asset in such circumstances will generate a tax loss of $\$ 50,000$. That loss appears illusory only as long as attention is focused on $A$ 's income stream, which appears to be unchanged, since he can reinvest the $\$ 50,000$ proceeds of his sale at 10 percent to generate $\$ 5,000$ a year. Once attention is shifted from $A$ 's income to his capital, however, it becomes clear that he is worse off by $\$ 50,000$. Compared to a taxpayer $B$, who had kept his $\$ 100,000$ in a checking account throughout this period, $A$ has definitely suffered a loss because $B$ can now purchase two assets of the type $A$ holds with the same amount of money $A$ originally invested in one. Similarly, if $A$ disinvests one quarter of his capital for consumption, he will be able to command only half as many goods and services as can taxpayer $G$, who receives a $\$ 25,000$ salary, which has been unaffected by the change in interest rates, whereas before the rise in interest rates a quarter of $A$ 's capital would have bought him the same goods as C's salary. like a change in the general price level, the effect of changes in interest rates does not present a convincing case for denying the theoretical validity of a deduction for capital losses under a net income tax. See L. SeLrzer, supra note 4, at 93, 98; Break, supra note 4 , at 222-24.

24 See, e.g., Klem, The Stock Exchange Point of View on Capital Gains Taxation, 46 Nat'l TAX Ass'n Conf. ProceEd. 138, 141 (1954).

25 See, e.g., Staffs of the Joint Comm. on Internal Revenue Taxation and Senate Comm. on Finance, Hearings on the Tax Reform Act of 1969 Before the Senate Comm. on Finance, 91st Cong., 1st Sess. 95 (1969); H.R. ReP. No. 749, 88th Cong., lst Sess. 96, A134-37 (1963), 1964-1 Cum. Burr. 220-24, 382-85; H.R. REP. No. 1860, 75th Cong., 3d Sess. 33 (1938), 1939-1 Cum. Bull. (Part 2) 751; Subcomm. of the House Comm. on Ways and Means, supra note 17 , at 31 . 
would be more willing to take substantial risks, subjecting any profit to the possibility of taxation, if losses could be deducted from other income. ${ }^{26}$

The proposition that loss deductions will encourage risk taking has more than intuitive economic support. Evsey D. Domar and Richard A. Musgrave $^{27}$ reasoned that in every investment decision the rational investor must weigh the advantage of a greater return, or yield, against the disadvantage of a possible loss or risk. A proportional tax without a provision for offsetting losses would reduce only the yield, so that compensation per unit of risk taking would be less. With risk taking less attractive, investors might take fewer risks than if there were no tax, or they might tend toward more risk taking in order to regain the money lost to the $\operatorname{tax}_{.28}$ While the theoretical result of these contrary forces was uncertain, empirical evidence indicated that investors were likely to hold less risky assets under a proportional tax regime with no offsets than they would if there were no tax at all.

A proportional tax with full offsets, on the other hand, would stimulate risk taking. Because risk and yield would be diminished to the same degree, the introduction of taxation would not affect return per unit of risk taking and would not create an incentive to diminish risk taking. At the same time, to the extent that investors are induced to take risks to replace income taxed away, risks taken by taxpayers granted loss offsets would exceed those taken under a system of taxation without such offsets. Indeed, to the extent investors seek to recover income taxed away, a proportional tax on gains with full offset of losses would stimulate more risk-taking for society as a whole-including the share borne by the Treasury-than would a scheme in which gains are not taxed at all.29

26 The argument has been made often. See M. DAvid, supra note 4, at 140-41; H. Groves, Postwar Taxation and Economic Progress 221 (1946); L. Kimmed, TaXes and Economic Incentrves 97-99 (1950); A. Moulton, G. Edwards, J. MAgee \& C. Lewis, Capital EXPANSTON, EMPLOYMENT, AND ECONOMIC StABILITY 296-97 (1940); 2 REPORT OF THE Royal [Canadian] CoMmission on TAXation 155 (1966); L. Seltzer, supra note 4, at 183-84; Statements of M.L. Seidman, representing the New York Board of Trade, in Hearings on the Revenue Act of 1934 Before the Senate Comm. on Finance, 73d Cong., 2d Sess. 40 (1934); Keith, Tax Policy and Investment, 266 AnNals 77, 83 (1949); Kent, The Question of Taxing Capital Gains: The Case for Taxation, 7 LAw \& ConTEMP. Prob. 194, 206 (1940); Lowndes, supra note 18, at 457. A clear congressional model for full deductibility exists in 1958 legislation granting original investors in certain small business stock ordinary rather than capital treatment of their losses. Int. Rev. Code of 1954, §§ 1242-1244; see Smith, Tax Treatment of Capital Gains, in U.S. Congress House Comm. on Ways and MEANs, 2 TaX ReviSION COMPENDIUM 1233, 1235 (1959).

27 Domar \& Musgrave, Proportional Income Taxation and Risk-Taking, 58 Q.J. EcoN. 388 (1914).

28 Id. at 422.

29 In the quarter century since their paper was first published, Domar and Musgrave's 
Although Domar and Musgrave examined only the effects of a proportional tax on risk taking, they considered the conclusion that the tax laws should be adjusted to create the conditions most favorable to deducting losses even more appropriate under a progressive income tax. The sparse empirical-attitudinal evidence that exists does not document the predicted willingness to take greater risks to offset progressive taxes, ${ }^{30}$ but it would be a mistake to conclude on that basis that making losses deductible would not encourage risk taking. Even if taxation with a deducton for losses would induce no more total risk taking than nontaxation, it would still stimulate more private risk taking than taxation without a loss deduction.

In addition, the tax savings made possible by the deferral effect of currently deducting losses while postponing gains ${ }^{31}$ could make risk taking even more attractive than the Domar-Musgrave hypothesis would indicate.

theoretical model has been subject to modification and criticism. See C. HAIr, Fiscal Policy for Stable Growth 164-73 (1960); R. Musgrave, The Theory of Public Finance 312-25 (1959); E. RoLPh, THE THEORY OF Fiscal Economics 285-302 (1954); Feldstein, The Effects of Taxation on Risktaking, 77 J. PoL. EcoN. 755 (1969); Litner, The Valuation of Risk Assets and Selection of Risky Investments in Stock Portfolios and Capital Budgets, 47 Rev. Econ. \& Statistics 13 (1965); Mossin, Taxation and Risk-Taking: An Expected Utility Approach, 35 EcoNomica 74 (1968); Näslund, Some Effects of Taxes on Risk Taking, 35 REv. Econ. Stud. 289 (1968); Penner, A Note on Portfolio Selection and Taxation, 31 REv. ECON. STUD. 83 (1964); Richter, Cardinal Utility, Portfolio Selection, and Taxation, 27 REv. Econ. STUd. 152 (1960); Roy, Safety First and the Holding of Assets, 20 EconomerRICA 431 (1952); Stiglitz, The Effects of Income, Wealth, and Capital Gains Taxation on Risk-Taking, 83 Q.J. Econ. 263 (1969); Streeten, The Effect of Taxation on Risk Taking, 5 OXF. ECON. PAPERS (N.S.) 271 (1953); Tobin, Liquidity Preferences as Behavior Towards Risk, 25 REv. Econ. STud. 65 (1958); Tobin, The Theory of Portfolio Selection, in THE THEORY OF INTEREST RATES (F. Hahn \& F. Brechling eds. 1965).

Their basic conclusion that proportional taxation with loss offsets encourages risk-taking is now widely accepted by economists. See, e.g., Feldstein, supra, at 755; Helliwell, The Taxation of Capital Gains, 2 CaN. J. Econ. 314 (1969); Russell \& Smith, Taxation, RiskTaking and Stochastic Dominance, 36 So. Econ. J. 425 (1970).

30 In a 1949 Harvard Business School survey of about seven hundred fifty high-income investors, the income effect was found to play an insignificant role in taxpayer motivation. J. Butters, L. Thompson, \& L. Bollinger, EFfects of TAXation: INVESTMENTS BX INDIVIDUats 41-43, 181-204 (1953). Those findings are summarized in Thompson \& Butters, Effects of Taxation on the Investment Policies and Capacities of Individuals, $8 \mathrm{~J}$. Finance 137, 142-48 (1953). Basically, high income tax rates tended to drive income-minded investors into low-yield, low-risk investments because the surtax rates reduced returns from corporate securities below acceptable levels. There were a few instances in which tax considerations stimulated an increase in holdings of common stock because the investor was under pressure to maintain a given level of income, and a few in which the "income effect" was identifiable but was associated predominately with nontax factors such as increases in the cost of living. Even taxpayers who were appreciation-minded were more responsive to the preferential treatment given capital gains than to the detrimental limitations on the deductibility of capital Iosses.

31 See text at notes $86-88,96-97$ infra. 
In summary, the case for full deductibility rests primarily32 on two grounds: (1) in its impact on a taxpayer's ability to command goods and services, a capital loss is indistinguishable from any other loss incurred in a gain seeking transaction; and (2) full deductibility would have beneficial economic effects. ${ }^{33}$ Despite the analytic and practical appeal of the case for full deductibility, however, competing considerations have held sway in Congress since 1924.

\section{The Case for Limiting Deductibility}

The protean restrictions ${ }^{34}$ that Congress has placed on capital loss deductibility have been variously justified by reference to three objectives:

32 Other arguments for full deductibility are more problematic.

(1) Full deduction of losses would strengthen the countercyclical effect of the income tax by leaving additional cash in taxpayers' hands during a period of declining prices. Blum, supra note 20, at 265. Attractive in theory, whether taxpayers would avail themselves of this possibility in a new depression is as yet empirically unverified. In any event, the decline in the relative revenue importance of the capital asset provisions lessens the significance of the countercyclical effects of full deductibility. See text at notes 40-44 infra.

(2) "Capital losses can serve to ease the financial strain on taxpayers that may accompany realization of losses." TREASURY DEP'T STUDY, supra note 4, at 61. To the extent this argument goes beyond the net income and incentive rationales to assert that investors suffering investment losses should be given federal tax relief, like taxpayers suffering casualty losses, for nontax reasons, it is beyond the scope of this analysis.

(3) Heavy taxation of gains with limited deductions for losses is a one-way street which always benefits the Treasury; if the government is going to take a large share of any capital gain, it should share heavily in any capital losses. See SUBCOMM. OF THE House Comm. oN WAYS AND MEANS, supra note 17, at 30; Statement of Chester Leasure, Chamber of Commerce of the United States, Revenue Act of 1934, in Hearings Before the Senate Comm. on Finance on H.R. 7835, 73d Cong., 2d Sess. 53 (1934); Schram, Taxation and Venture Capital, 266 ANNars 85, 90 (1949). On a technical level, an argument based on the relative benefit of gains and losses to the government and investors would appear only to mandate deductibility of losses to the extent that gain is taxed. Like other arguments for parallel treatment of gains and losses, it fails to recognize that gains and losses are not generally realized by the same groups of taxpayers, and it flounders on the definitional ambiguities inherent in tax parallelism. See text at notes 52-69 infra.

The same argument is sometimes framed in terms of taxpayer psychology: regardless of the realities of tax incidence or the ambiguities of tax theory, taxpayers may feel that the government has stacked the deck against them by considering gains more than losses in the computation of taxable income. See H. Groves, supra note 26, at 222; F. Groves, Production, Jobs and Taxes 82 (1944); Miller, Existing and Proposed Provisions of Law Regarding Capital Gains and Losses, 32 NAT'L TAX Ass'N CONF. ProceED. 126, 128-29 (1939). Taxpayer morale and understanding are obviously relevant considerations since they directly affect the administration of the statute. The case for taxpayer dissatisfaction so great as to affect either the efficiency or the acceptance of the tax has not been made, however. Indeed, what empirical evidence we have suggests investors are more concerned with the preferential treatment given gains than the detrimental treatment given losses. See note 30 supra.

33 See, e.g., Slitor, The Carter Proposals on Capital Gains: Economic Effects and Policy Implications for the United States, 22, NAT'L TAX J. 66 (1969).

34 See notes 1-3 supra. 
protection of the fisc, parallel treatment of capital gains and losses, and the prevention of tax avoidance.

\section{A. Protection of the Revenue}

Limitations on the deductibility of capital losses have been justified as necessary to protect federal revenues ${ }^{35}$ on the theory that losses, if fully deductible, would be realized immediately in periods of declining prices, seriously impairing the tax yield ${ }^{36}$ and exerting further downward pressure on securities prices. ${ }^{37}$ This argument, which grew out of the particular circumstances of the Great Depression, ${ }^{38}$ is based on uncertain facts and discarded economics. In addition, it does violence to the concept of net income taxation.

No one would advocate the elimination of all the deductions and credits in the present tax law simply to balance the budget. ${ }^{30}$ To do so would convert the net income tax into a levy on gross income. Elimina-

85 The loss limitations introduced in the 1930s were presented as revenue protection provisions. See H.R. REP. No. 708, 72d Cong., Ist Sess. 12-13 (1932), 1939-1 Cum. BuLx. (Part 2) 465; H.R. REp. No. 704, 73d Cong., 2d Sess. 10 (1934), 1939-1 Cum. Burc. (Part 2) 562; Prevention of Tax avoldance, Prelmminary Report of a Subcomm. of the house Comm. on Ways and Means, 73d Cong., 2d Sess. 6, 32-37 (Appendix Exhibit C) (Comm. Print 1933); SUbComm. OF THE House CoMm. on WAYs aND MEANS, strpra note 17, at 32 H.R. REP. No. 1860, 75th Cong., 3d Sess. 7-9, 33-42 (1938), 1939-1 Cum. BuLt. (Part 2) 732-33, 751-58.

86 As recently as 1951, the Treasury Department stated that the belief that federal revenues should be protected in the event of a severe price decline was "the principal basis for modern loss limitations." TREASURY DEP'T STUDY, supra note 4, at 62 . Similar statements can be found throughout the literature. See, e.g., W. Shultz \& G. Harriss, American Publrc FinaNce 248 (1965); Blum, supra note 20, at 254.

37 See G. CoNWAY, supra note 11, at 191. The asserted effect on securities exchanges is typically a part of the broader position that both capital gains and losses should be excluded from taxable income because taxation promotes instability in the capital markets. See Colm \& Lehman, Economic Consequences of Recent American Tax Policy, Social RESEARCh 66-68 (Supp. I, 1938); Fisher, A Practical Schedule for an Income Tax, 15 TAXEs 379 (1937); Tremaine, The Capital Gains Tax, 15 Taxes 517, 567 (1937). Its theoretical underpinnings are a supply and demand analysis that is best articulated in Somers, $A n$ Economic Analysis of the Capital Gains Tax, I NAT'L TAx J. 226 (1948). For attacks on Somers' model for its failure to account for the multitude of other factors that infuence security prices, see, for example, Heller, Investors' Decisions, Equity and the Capital Gains Tax, in U.S. CONGRESS, JOINT COMMITTEE ON THE ECONOMIC REPORT, FEDERAL TAX POLICY FOR ECONOMTC GROWTH AND STABILITY 381, 387-89 (1955); Richman, Incentive Effects of Alternative Tax Treatments of Capital Gains, 53 NAT'L TAX Ass'N ProceEd. 597, 600 (1961).

The supposed aggravation of security price declines has never been quantitatively determined. M. DAvID, supra note 4, at 3. Comparing thirty years of realization of capital gains and losses with movements on the New York Stock Exchanges, Seltzer concluded there was a general, though far from perfect, correspondence between the two, but that the tax system could not be said to be the predominant influence on market fluctuations. L. SELTzER, supra note 4, at $119,156-80$.

38 See Parker, Capital Gains and Losses, 14 Taxes 604, 607 (1936).

30 Kent, supra note 26, at 202. 
tion of particular deductions for revenue purposes is no more defensible. The decline in revenue during a depression could be remedied in a number of ways, such as raising rates, that do not violate the principle of net income taxation. That an increase in capital losses might have contributed to the decrease in revenues should not be controlling in deciding how to replace the revenues lost. The revenue loss from deduction of fixed-cost business expenses that are high in relation to low depression sales would hardly justify elimination of the business expense deduction. The principle of net income taxation protects against such an inequity.

In addition, the effect on federal revenues postulated by the revenue protection argument is quite uncertain. At least some taxpayers may prefer to save their losses to level out their income in the future. ${ }^{40}$ More importantly, changes in the structure of the federal income tax make it unlikely that full loss deductibility would have the significant impact on tax revenues that it might have had in the 1930s. In 1928, nearly 50 percent of total individual income tax receipts were attributable to capital gains. ${ }^{41}$ As the base of the personal income tax has been broadened and the rates increased, however, the relative importance of capital asset transactions for the federal revenues has declined dramatically: during the ten-year period 1938 through 1947, the total yield from capital gains taxation was less than 3 percent of the total yield from personal income taxation. ${ }^{42}$ While the yield from capital gains as a percentage of total income and excess profits taxes has increased in the years since 1948, it had not as of 1963 exceeded 5.7 percent in any year. ${ }^{43}$ Although the dramatic growth of income tax yield from sources other than capital gains does not entirely insulate federal revenues from the effects of a precipitous decline in capital asset values, the Treasury is surely correct in concluding that the revenue rationale for current loss limitations is "less important" today than it was in the 1930s.

Finally, the underlying economic assumption of the revenue protection rationale-that declining revenues in a depression are detrimental to government finance or the economy as a whole ${ }^{44}$-is now doubtful.

40 Blum, supra note 20, at 254.

41 Treasury Dep'T Study, supra note 4, at 45 . The proportion exceeded 40 percent in the four years $1926-29$ as a whole. Id. Estimates of revenue yield from capital gains taxation are subject to a large margin of error because consistent information is not available for all years and because differences in statutory provisions make comparisons difficult. Treasury DEP'T STUDY, supra note 4, at 45 .

42 TrEasury Dep'T Study, supra note 4 , at 46.

$43 \mathrm{M}$. DAvin, supra note 4 , at $64-65$. Figures include corporate tax returns. The average proportion for the years 1959-62 was about 4 percent. $I d$.

44 Bangs, The Dilemma of the Cut-Rate Tax, 31 TAxEs 31, 36 (1953). The revenue argu- 
Post-Keynesian economic theory suggests that during a period of depression, an increase in consumer purchasing power might be precisely what is needed to help stimulate recovery. To the extent that loss deductions reduce tax bills in such periods, taxpayer purchasing power would increase automatically.

The contemporary dubiety of the economic assumption on which the revenue protection argument is based does not directly detract from the logic of the argument for continuing to limit capital loss deductions. Together with the uncertain nature of the postulated effect on revenues, however, it does remove the nontheoretical props that might otherwise have supported a departure from the principle of net income taxation. ${ }^{45}$

\section{B. Paralleling the Preferential Taxation of Capital Gains}

When the Ways and Means Committee first accepted preferential flat rate treatment for capital gains, it recommended at the same time a parallel flat rate deduction for capital losses. ${ }^{46}$ Congress finally adopted

ment may also be framed in terms of revenue stability rather than absolute amount: allowance of loss deductions would lessen revenues in depression years while large receipts are generated in prosperous years. Prevention of TaX Avomance, Preliminary Report of a Subcomm. of the House Comm. on Ways and Means, 73d Cong., 2d Sess. 32-37 (Appendix Exhibit C) (Comm. Print 1933); Caine, Taxation of Capital Gains and Losses, 20 TAXEs 139, 141 (1942). Instability of revenue yield has traditionally been considered undesirable because it makes budget balancing difficult and might therefore endanger the government's credit. L. SELTZER, supra note 4, at 205 . Since the 1930 s many economists have come to consider stabilizing revenue less important than stabilizing the economy as a whole. $C f$. M. DAvm, supra note 4, at 62-65, asserting that reported realization of capital gains appears to have operated as a stabilizing influence in most of the postwar period.

45 In yet another form of the revenue argument, it is said that in the long run taxation of capital gains and losses nets the government little, if any, revenue and should be eliminated because of the administrative costs it entails. Because it questions the treatment of gains as well as losses, that form of revenue argument lies beyond the scope of this article. It should be noted, however, that the factual premises and policy conclusions have both been disputed; some commentators assert that equity demands taxation of gains even if net revenues are reduced in the long run by the deduction of losses, Alvord, Capital Gains and Undistributed Profits Taxes: A Suggested Program, 16 TAxes 145, 147 (1938); Caine, supra note 44 , at 184 , while others argue that eliminating the tax on capital gains would increase administrative expenses because taxpayers would have an even greater incentive than at present to minimize their taxes by shifting receipts from ordinary income to capital gains characterization. See, e.g., L. SeltzER, supra note 4, at 209-10; TrEasUrY DeP'T STUDY, supra note 4, at 42; TwENTIETH CENTURY Fund, supra note 11, at 486.

46 H.R. 8245 (Union Calendar No. 140), 67th Cong., 1st Sess. § 206 (1921); see H.R. REP. No. 350, 67th Cong., 1st Sess. 10-11 (1921), 1939-1 Cum. Bull. (Part 2) 176; J.S. SEIDMan, SEIDMAN's LEGISLATIVE HISTORY OF FEDERAL INCOME TAX LAws, 1938-1861, at 813 (1938). After the Senate failed to agree with the House's proposal in 1921, the Secretary of the Treasury joined in calling for parallel limits on deductions. REPORT OF THE SECRETARY OF THE Trensurx 14 (1922). The House passed such legislation again in 1923, but the Senate declined to act. See H.R. REP. No. 1388, 67th Cong., 4th Sess. 2 (1923); 64 CoNG. REc. 2919-21, 5579-80 (1923). 
the recommendation in 1924,47 apparently adopting the committee's argument that such treatment is justified as a matter of logic: "If the amount by which the tax is to be increased on account of capital gains is limited to $121 / 2$ per cent of the capital gain, it follows logically that the amount by which the tax is reduced on account of capital losses shall be limited to $121 / 2$ percent of the loss." 48

1. Definitional and Technical Problems. The argument that preferential taxation of capital gains mandates parallel limitations on capital loss deductibility has remained powerful in its appeal to Congress. ${ }^{49}$ Since its inception, however, it has suffered from a crisis of definition. Assuming only partial taxation of gains, what is "parallel" treatment of losses? Three answers have been suggested.

a. Liability/Savings Parallelism. According to the Treasury Department, the "phrase 'parallel treatment for capital gains and losses' usually refers to a set of tax provisions under which losses will reduce tax liability by the same percentage that a gain of corresponding size would increase it." ${ }_{0}$ This interpretation of parallel treatment underlay the 12.5 percent credit for capital losses, "parallel" to the 12.5 percent tax on capital gains in the Revenue Act of 1924, as well as the 30 percent maximum credit for long-term losses, "parallel" to the 30 percent alternative tax for long term gains, in the Revenue Act of 1938.51

Under this view, parallelism of treatment derives from the expectation that tax liability and tax savings will be equal for equal amounts of gain and loss. Although the Treasury statement of this position is phrased in terms of equivalence in the percentages of tax liability and

47 Revenue Act of 1924, ch. 234, §§ 208(b)-(c), 43 Stat. 253; see H.R. REP. No. 844, 68th Cong., Ist Sess. 15 (Amendment 30) (1924), 1939-1 Cum. Burc. (Part 2) 301.

48 H.R. REp. No. 179, 68th Cong., Ist Sess. 57 (1924), 1939-I Cum. Burr. (Part 2) 255.

49 The step scales of the Revenue Acts of 1934 and 1938, see note 3 supra, perpetuated parallel treatment of gains and losses through the identical recognition percentages applied to each. When the step scale was eliminated in 1942, dollar ceiling and percentage recognition restrictions were placed on capital losses "to compensate the Government for the reduced tax rate applicable to capital gains." H.R. REP. No. 2333, 77th Cong., 2d Sess. 30 (1942). As recently as 1969, Congress limited to fifty cents the amount of ordinary income reduced by each dollar of net long-term capital loss in excess of net short-term capital gain in order to be "consistent" with the inclusion in taxable income of only fifty cents of each dollar of net long-term capital gain in excess of net short-term capital loss. H.R. REp. No. 413 (Part 1), 91st Cong., 1st Sess. 6-7 (1969); 1969-3 Cum. Bull. 203; S. Rep. No. 552, 91st Cong., Ist Sess. 190-97, 200 (1969), 1969-3 Cum. BuLc. 423, 544, 548, 550; see Maxfield, Capital Gains and Losses, 25 TAX L. REv. 565, 570 (1970). For references to the notion of tax parallelism outside the legislative context, see Comemitree on Postwar Policy, A TaX Program for A Solvent America 99-100 (1945); G. Convay, supra note 11, at 196; R. Paul, Taxation FOR PROSPERTTY 276 (1947); L. SELTZER, supra note 4, at 182-83.

50 TREASURY DeP'T Studx, supra note 4, at 63.

51 See note 3 supra. 
tax savings, the absolute amounts will also be identical. Thus, if $\$ 1,000$ of capital gain increases tax liability by 20 percent of the gain ( $\$ 200)$, reduction of tax liability the same percentage (20 percent) of an equivalent loss $(\$ 1,000)$ would yield tax savings equal in absolute terms to the tax increase $(\$ 200)$.

As the Treasury recognizes, however, parallelism of this sort can be effected only by a flat rate tax and tax credit.52 Offsets under a graduated income tax, computed after gains are added to, and losses deducted from, gross income yield very different results. Assuming for the moment that ordinary income does not fluctuate, realizing net capital gains of a sufficient magnitude would push a taxpayer into a higher tax bracket, while realizing net capital losses of a sufficient magnitude would put him into a lower bracket. Consequently, equal amounts of gain and loss could have different degrees of tax impact: because of the graduated rate structure, ${ }^{63}$ realization of a net gain could result in a greater increase in tax liability than the reduction in tax liability occasioned by realization of an equivalent net loss. When the assumption of constant ordinary income is removed, the tax saving and liability values of equivalent losses and gains become entirely unpredictable. ${ }^{54}$ Because fluctuations in ordinary income can also cause shifts in tax brackets, a capital loss could yield tax benefits less than, equal to, or greater than the tax liability created by realization of the same amount of gain in a different year.

The modern federal income tax system is thus inherently unparallel in the sense under discussion. Because a taxpayer may shift brackets, an increase in ordinary income may create more additional tax liability than the tax saving value of an equivalent reduction in ordinary income. Similarly, the tax saving from deductible capital losses turns on factors other than the hypothetical liability that would be incurred in the case of an equivalent gain.

b. Inclusion/Deduction Parallelism. A second version of parallelism focuses on the amounts of gains included in, and losses deducted from, taxable income, rather than the resulting tax liability or savings. The Revenue Acts of 1934, 1938, and 1942,,55 for example, recognized an equal percentage of gains and losses, and in 1954 the American Law Institute proposed that only 50 percent of capital gain or loss be taken

52 TREASURY DEP'T STUdY, supra note 4, at 63 .

$53 I d$. at 64 .

54 If gains are more likely to be realized during high-income years and losses during low-income years, taxpayers would incur higher rates of tax on gains than of tax saving on losses. Id.

65 See note 3 supra. 
into the computation of taxable income, with an alternative tax applied to both gains and losses. ${ }^{56}$ This proposal was defended on grounds of parallelism in that "capital losses provide deductions from income to the same extent that capital gains give rise to inclusions in income." 57

Unlike the liability/savings version of parallelism, inclusion/deduction parallelism is possible under graduated income taxation since the parallel treatment to which it refers occurs before the tax rates are applied. Indeed, it is the same kind of "parallel" treatment given business income (inclusion in gross income) and business expenses (deductions from gross income). Because the alternative tax effectively exempts certain capital gains from the graduated rates, however, the parallelism based on the amount of gain and loss taken into the computation of taxable income is not complete.

If the graduated rate structure makes complete tax liability/savings parallelism impossible while the alternative tax prevents complete realization of inclusion/deduction parallelism, a hybrid encompassing both versions of parallelism might seem an appropriate resolution. One test of parallelism or the other would be met with respect to each gain and loss. Taxpayers would deduct losses from income to the extent that gains are included, but such losses would be subject to a maximum tax credit to the extent that gains are subject to the alternative tax. ${ }^{58}$ Even if a maximum credit could be drafted to mirror the considerable complexities of the current alternative tax, however, fluctuations in ordinary income would prevent the hybrid from accomplishing either sort of parallelism in many cases. For instance, a taxpayer with a net loss in a low income year might deduct it from ordinary income while a net gain in a high income year might be subject to the alternative tax, so that neither test of parallelism between the gain and loss would be met. Similarly, a gain in a low income year might be included in ordinary income while a loss in a high income year could be subject to the maximum credit.

c. Accrual/Realization Parallelism. A third version of parallelism, concentrating on the differences between accrual and realization systems of graduated income taxation, argues for preferential treatment of losses

56 ALI Fed. Income TAX STAT. §§ X231(b), X232 (Feb. 1954 Draft). See also J. McDonald, Gapital GaINS AND Losses 23-25 (1968), which suggests, in commentary on the Royal [Canadian] Commission on Taxation (Carter Commission) Report, that if 50 percent of realized gains are to be included, 50 percent of losses should be deductible up to, but not above, the income level at which the maximum marginal rate on gains is reached.

57 ALI Fed. Income TAX StAT. \& X232(c), at 345 (Feb. 1954 Draft).

58 The All's 1954 proposal, id., which provided for an equivalent tax and tax credit as well as limited recognition of gains and losses, was such a hybrid. 
as well as gains. ${ }^{59}$ Just as the realization criterion for progressive taxation of capital assets transactions results in greater taxation of a net longterm capital gain than would occur if the gain were spread evenly over the years during which it accrued-assuming constant ordinary income-so the deduction of a net long-term capital loss on realization results in a smaller tax reduction than would occur if the capital loss were spread evenly for tax purposes over the years of its accrual. Taxation of both long-term gains and losses would more closely approximate the results under an accrual system, therefore, if gains were only partially includible in taxable income and losses were granted more than full deductibility; that is, less than one hundred percent inclusion of gains coupled with greater than one hundred percent deduction of losses.

The assumption of constant ordinary income is obviously unrealistic. It would not be necessary to the argument for accrual/realization symmetry if a taxpayer could even out the peaks and valleys in his taxable income through general averaging. Since the averaging provisions of the Internal Revenue Code ${ }^{00}$ do not eliminate all significant fluctuations in ordinary income, however, long-term capital losses realized to average out annual income could reduce taxes by more than would the same Iosses spread out evenly ${ }^{61}$ __precisely the opposite of the assumption on which accrual/realization parallelism rests. The tax reduction value of losses taken in years of unusually high tax liability would be even larger if more than one hundred percent deductibility were permitted.

Thus, no concept of parallelism-tax liability/savings, inclusion/ deduction, or accrual/realization—can be fully implemented within the current tax structure. On the other hand, each version offers a rough symmetry, with technical imperfections that might be regarded as de minimis. If so, one need only select the superior version of parallelism, but here one searches in vain for guidance. There is no reason to believe that any one variant of symmetry is any more (or less) symmetrical than the others. Each has its own internal logic once the initial touchstone of parallelism-tax liability, income inclusion, or accrual taxation-is chosen, but there simply is no way to determine which touchstone is most consistent with the internal logic of the tax laws. Without that insight, there is no analytically defensible resolution of the definitional crisis from which the notion of parallelism in the taxation of gains and losses suffers.

59 See Break, supra note 4, at 224-25. See also L. SELTZER, supra note 4, at 182; Treasury Dep'T Study, supra note 4, at 64; W. VICRREX, AgENdA fOR Progressive TAXation 144 (1947); Bangs, supra note 44 , at 38.

60 INT. REV. CODE OF 1954, §§ 1301-05.

61 See Break, supra note 4, at 225. 
2. Distributional Problems. Even if the definitional dilemma could be resolved, the actual incidence of capital gains and losses would make any version of parallelism unacceptable as a matter of equity. Because gains and losses are netted together, ${ }^{62}$ those who receive the benefits of preferential gain treatment cannot, in the same year, be subject to limitations on loss deductibility. ${ }^{63}$ As between years, capital gains and losses do not appear to be distributed evenly among taxpayers who engage in capital asset transactions; ${ }^{64}$ gains are associated with large ordinary incomes, losses with ordinary incomes in the lower brackets. ${ }^{65}$ If gainers and losers are indeed different groups, it would be inequitable to make the price of one group's benefits the other's detrimental treatment.

Treating taxpayers with capital gains and/or losses as a single group is not made equitable merely because it results, in the aggregate, in parallel treatment of gains and losses. ${ }^{66}$ Fairness in individual income taxation must be measured as between individuals. ${ }^{67}$ No one would maintain, for example, that considerations of parallelism and equity between the government and taxpayers as a group would justify a decision to ignore commercial rents received and commercial rents paid in the computation of taxable income. Such a decision, by which the government might experience no significant change in revenues, would benefit commercial landlords at the expense of commercial tenants. Similarly, to limit the deduction of losses because gains are granted benefits, as tax liability/saving and inclusion/deduction parallelism would do, is to magnify the preferential treatment of gains at the expense of those taxpayers with losses. ${ }^{68}$ The result is particularly inappropriate in the context of a graduated income tax where gains are associated with the upper brackets and losses with the lower.

The apparent distribution of gains and losses to different groups also makes the preferential treatment of losses required for accrual/realization parallelism unacceptable. While there is no a priori reason to treat gainers and losers similarly, it is true that both groups experience the detrimental effect of realization taxation. If taxpayers with capital gains

62 INT. REv. CoDE OF 1954, §§ I201, 1223.

63 See INT. REV. CODE OF 1954, §§ 1202, 1211, 1222.

64 TREASURY DEP'T STUDY, supra note 4, at 63.

65 See H. Groves, supra note 26, at 181; H. SIMONS, supra note 12, at 159-60; TREASURY DER'T Study, stupra note 4, at 49, 63. See also R. BARLOW, H. BRAZER \& J. Morgan, EcoNOMT BEHAVIOR OF THE AFFLUENT 124 (1966); M. DAVID, supra note 4, at 81-91; L. SELTZER, supra note 4, at 117-19, 124-31.

68 Bangs, supra note 44, at 35; Kent, supra note 26, at 197; Lowndes, supra note 18, at 448.

67 H. Simons, Federal TAX REForm 71 (1950); Blum, supra note 20, at 251.

08 TAX INSTITUTE, INC., supra note 19, at 13; Bangs, supra note 44, at 35. 
are thought to be granted preferential treatment in part to approximate accrual taxation, however, perhaps all other groups adversely affected by the decision to tax on a realization basis should also receive special benefits. But there is no distinction on which to single out one additional such group-taxpayers with capital losses-for preferential treatment. ${ }^{60}$

In summary, the argument for limiting the deductibility of capital losses as a parallel concomitant of preferential treatment of capital gains, like the revenue protection rationale, fails to overcome the case for full deductibility. None of the suggested versions of parallelism can be fully implemented in our tax system and, more importantly, there is no way to choose among them. Finally, the distribution of gains and losses makes each version unacceptable, even if there were some analytically defensible ground for choosing it over the others.

\section{Prevention of Tax Avoidance}

The third and most formidable argument for limitation-that unlimited deductibility of capital losses would invite tax avoidance-has always had adherents. ${ }^{70}$ As in most arguments from tax avoidance, the danger to the government is stigmatized as "unconscionable"71 "manipulation," 72 and "an invitation to the speculator to share with his fellow citizens the ill results of a speculation that has gone wrong," "73 but, as with many such excoriations, the precise objection to the denigrated behavior is not always clear.

One possibility for tax avoidance inherent in full deductibility might be thought to be the deduction of sham losses, in which a tax loss is created without change in the taxpayer's economic position. While the tax laws have indeed had to respond regularly to taxpayer ingenuity in creating fictitious capital losses, ${ }^{74}$ these problems arise whether losses are deducted from ordinary income or offset against capital gains. Even if it were thought that allowing taxpayers to deduct net capital losses

68 It is appropriate to consider whether parallelism would justify loss limitations in the event the distribution of gains and losses were different. The short answer is that there is nothing inherently desirable about symmetry in the tax laws. If different policy considerations apply to gains and losses, they should be taxed differently, rather than according to some predetermined notion of harmony.

70 See, e.g., REport of the SECREtary of the Treasury 14 (1922).

71 G. CONWAY, supra note 11 , at 165.

72 Blum, supra note 20 , at 254.

73 Royal Commission on Taxation [U.K.] of Proftrs and Income, supra note 18, at 30.

74 See INT. REv. CoDE of 1954, \& 1091 (wash sales), first enacted as Revenue Act of 1921, ch. 136, § 214(a)(5), 42 Stat. 240; INT. REv. CODE OF 1954, § 267 (transactions between related individuals, including those with controlled corporations), first enacted as Revenue Act of 1934, ch. 277, \& 24(a)(6), 48 Stat. 691. See generally TrEAsURY DEP'T STUDY, supra note 4 , at $62-63$. 
from ordinary income might prove a greater incentive to the creation of fictitious losses than allowing deductions from capital gains, ${ }^{75}$ the possibility of sham loss deductions does not establish the case for limitations on the deductibility of real capital losses deductions.

A second possible objection to full deductibility based on grounds of tax avoidance is that wealthy taxpayers with large portfolios might be able to reduce their tax liability every year almost to zero by culling enough losses to offset whatever capital gains ${ }^{76}$ and ordinary income they had realized during the year. ${ }^{77}$ The precise objection to this practice is obscure. If it is that the resulting reduction in tax receipts would threaten the federal coffers, the assertion is but a narrow version of the revenue protection argument discussed above. ${ }^{78}$ If the objection is that folks like J. P. Morgan ${ }^{79}$ would get away without paying taxes, the question of the appropriate tax treatment of losses is begged by an ad hominem polemic against the wealthy.

A third and more convincing case for limiting the deductibility of net losses on grounds of tax avoidance rests on the taxpayer's control over the timing of realization for his capital losses. This power creates two possibilities for tax avoidance, each of which deserves detailed analysis.

\section{Partial Taxation of Gains and Full Deduction of Losses. By real-}

75 Cf. 53 CoNG. Rec. 13, 264 (1916) (statement of Mr. Williams).

76 R. BARLow et al., supra note 65, at 5, 126-27 (1966) shows that realization of losses is associated with realization of gains. But see L. SELTZER, supra note 4, at 189; Bock, Reno, Seghers \&: Seidman, Comments on Sixteen Proposals for Revising Federal Taxes: A Symposium, 83 J. Accountancy 463, 466 (1947); Hahne, Taxation of Gapital Gains, 7 Taxes 20, 24 (1929).

77 The tightened loss provisions of 1934 grew, in part, out of concern for such "avoidance." Just as the National Industrial Recovery Act, which included a few tax provisions, was about to be brought to the House floor in 1933, J. P. Morgan testified before a Senate committee investigating exchange practices that he and his partners had paid no federal income taxes in 1932, largely because of capital loss deductions; in the first days of 1931, the firm incurred deductible losses totaling a spectacular $\$ 21,000,000$. Hearings Before the Senate Comm. on Banking and Currency on Stock Exchange Practices 42, 878 (1933). See also S. Rep. No. 1455, 73d Cong., 2d Sess. 321-31 (1934). In Great Britain, where capital gains and losses were not taken into the calculation of taxable income, the firm had continued to pay income taxes. In the wake of the public outcry that accompanied these disclosures, the National Industrial Recovery Act and the Revenue Act of 1934 added new limitations on the deductibility of capital losses. The former eliminated the security loss carryover of 1932 before it could take effect, as well as the exemption of private bankers from the security loss restrictions of the Act of 1932, and prohibited partners from deducting security losses disallowed the partnership from their individual income. National Industrial Recovery Act, ch. 90, § 218, 48 Stat. 209 (1933). For a description of the 1934 Act, see note 3 supra.

78 See text at notes 35-45 supra.

79 See note 77 supra. 
izing his gains and losses in different years, a taxpayer would be able to avoid the netting provisions, thereby generating tax savings where there is no change in economic position. The examples that follow illustrate situations in which this could be done.

a. The Section 1201 Differential. A taxpayer with a $\$ 10,000$ longterm gain and a $\$ 10,000$ long-term loss has experienced no change in his net economic position. If the gain and loss are realized in the same year, he will experience no tax effect either. If the loss were fully deductible and the gain subject to the alternative tax of section 1201, however, substantial tax savings could be generated by realizing the gain and loss in different years. The tax on his $\$ 10,000$ gain subject to an alternative tax of 25 percent would be $\$ 2,500$, while the tax savings from his $\$ 10,000$ loss deduction at, let us say, a marginal rate of 60 percent, would be $\$ 6,000$ - a net tax savings of $\$ 3,500$ from realizing the gain and loss in different years.

If the loss were short-term rather than long-term, precisely the same differential would obtain. The result could be considered less objectionable, on the theory that short-term losses should be deductible in full because short-term gains are taxed in full, but that argument only leads back to the quagmire of parallelism where loss treatment turns on the taxation of gains. It is not responsive to the assertion of this section that whatever one's view of the merits of symmetry, full deductibility would permit certain taxpayers to create tax savings on transactions that have no other financial effect.

b. The Section 1202 Differential. Where the alternative tax on capital gains does not apply, the section 120250 percent deduction of net long-term capital gain (minus net short-term capital loss) would still enable the taxpayer to generate tax savings by realizing his gains and losses in separate years. Consider again the taxpayer with a $\$ 10,000$ longterm capital gain and a $\$ 10,000$ long-term capital loss that is fully deductible. If they are realized in different years, $\$ 5,000$ of the gain would be included in taxable income, increasing taxes, in the 40 percent bracket, by $\$ 2,000$ one year, while the $\$ 10,000$ loss would reduce taxes by $\$ 4,000$ in another year-a net tax saving of $\$ 2,000$. Once again, the same saving would be achieved if the loss were short-term rather than long-term.

c. The Section 1014 Differential. A taxpayer with a $\$ 10,000$ capital gain and a $\$ 10,000$ capital loss, if he holds both assets until death, will engender no income tax consequences for his estate because death is not an event that triggers realization. In addition, the gain and loss will, in effect, be cancelled for his devisees since, under section 1014, they will 
take the assets with a date-of-death basis.80 If, on the other hand, the taxpayer could deduct the full amount of the loss, long- or short-term, during his life-time, he would be able to reduce his taxable income by $\$ 10,000$ at, let us say, a marginal rate of 60 percent, for a $\$ 6,000$ tax saving. Meanwhile, the appreciated asset held until death will never increase taxable income or tax liability, leaving the taxpayer with a net tax savings of $\$ 6,000$ on transactions that had no net financial significance. Furthermore, unlike the section 1201 and 1202 differentials, this tax saving would obtain whether the unrealized gain at death were short-term or long-term since section 1014 applies to both. ${ }^{81}$

The gimmick in each of these examples is the same: the taxpayer could use his control over timing to separate the realization of capital gains and losses into different years in order to avoid the netting provisions. Thus, in situations in which there is no economic gain or loss, tax savings would be generated by combining partial (or no) taxation of capital gains with full deductions of capital losses. ${ }^{82}$

Coupling an ordinary deduction with a capital gain is, of course, a formula for avoidance prohibited elsewhere by the tax law. ${ }^{83}$ The present limitations on deducting capital losses provide a rough barrier to achieving the differentials discussed above by permitting a taxpayer to reduce ordinary income by only $\$ 1,000$ of capital losses annually, which encourages a taxpayer who realizes capital losses to realize capital gains in the same year. ${ }^{84}$ The requirement, enacted in 1969, that a dollar of net long-term capital loss be used to offset fifty cents of ordinary income ${ }^{85}$ also eliminates the section 1202 differential for a taxpayer with

80 Section 1014 actually gives the taxpayer the option of a date-of-death basis or one dependent on the alternate valuation date; the difference is not relevant to this discussion of the section.

81 Section 1014 grants a stepped-up basis to "property passed from a decedent," other than some DISG stock and property which constitutes a right to receive an item of income in respect of a decedent under section 691 . While the scope of section 691 is hardly clear, it does not appear to reach appreciation on property even if the appreciation is due to the decedent's own efforts. Ferguson, Income and Deductions in Respect of a Decedent and Related Problems, 25 Tax L. Rev. 5, 12 (1969); see Treas. Reg. § 1.691(a)-2(b) Ex. 5 (1957). Thus, some noncapital assets would be granted a stepped-up basis, making the section 1014 differential available where the unrealized gain might have been taxed as ordinary income. In theory then, the section 1014 differential should be eliminated not only with regard to capital gains, but also with regard to ordinary income assets within the scope of section 1014. The proposals advanced in the text do not go that far because their primary concern is with the treatment of capital assets.

82 The low rate of, and not insubstantial exclusions from, the minimum tax on tax preferences would keep that tax from effectively recapturing such savings. INT. REv. CoDE OF 1954, §§ 56-58.

83 See, e.g., Knetsch v. United States, 364 U.S. 361 (1960).

84 TREASURY DEP'T STUDY, supra note 4, at 61 .

85 INT. REv. CODE OF 1954, \& 1211(b) (1) (c)(ii). 
net long-term losses. Any plan for full deductibility of capital losses would have to include provisions to block the considerable opportunities for tax savings that removal of the existing restrictions would make available to investors with both unrealized gains and losses.

Because both depend on the preferential taxation of capital gains, it is important to notice the difference between the avoidance and the parallelism rationales for limiting the deductibility of capital losses. The parallelism argument is an assertion about how all capital losses should be treated, and turns on the method of taxing all capital gains. On the other hand, the argument that certain taxpayers could achieve differential taxation of their gains and losses under full deductibility is narrowly concerned with eliminating the potential for tax savings from taxpayer control over the timing of realizations that do not represent a net financial gain or loss. The avoidance rationale pertains only to certain investors-those with both unrealized gains and losses. The response it requires should not lead us back to the difficulties of a generalized parallelism because a solution to the problem of the differentials created by separating gains and fully deductible losses into different years need only be aimed at that identifiable class of taxpayers.

2. Income Averaging and Tax Deferral without Net Capital Gain or Loss. $^{86}$ A system in which changes in asset values are taken into tax computation only on the realization of gain or loss gives certain taxpayers the opportunity to reduce their taxes by deferral or averaging. A taxpayer who delays selling an appreciated asset receives the economic equivalent of an interest free loan from the government in the amount of the tax liability deferred. ${ }^{87} \mathrm{~A}$ taxpayer with appreciated assets and fluctuating ordinary income who realizes his gains in years of low ordinary income averages his taxable income over the years. If capital losses were fully deductible, a taxpayer who has only assets that have declined in value could similarly average out his taxable income by realizing losses in periods of high ordinary income.

The tax saving from income averaging that results from realizing net losses would be identical to that currently available from averaging through realization of net gains. The additional averaging and deferral possibilities that full deductibility would provide to a taxpayer who has both unrealized gains and losses would, however, be different in kind. Under present law, gains and losses realized in the same year must be

86 See M. Davm, supra note 4, at 8; R. Goode, supra note 22, at 195-96. See also J. PECHMAN, FEdERAI TAX POLICY 92-93 (1966); Groves, The Taxation of Capital Gains, in U.S. Congress, House Comm. on Ways and MEANs, 2 TAx Reviston Compendium 1198, 1200-01 (1959); Blum, supra note 20, at 254.

87 W. ANDREWS, FEDERAL INCOME TAXation $\$ 9.07$, at 150 (1969). 
netted, and the limitations on the deductibility of capital losses from ordinary income simultaneously discourage taxpayers from realizing their gains and losses in different years. Under a system of full deductibility, a taxpayer could avoid netting gains and losses by splitting them into different years, thereby achieving the benefits of averaging or deferral-quite apart from the section 1201, 1202, and 1014 differentials. A taxpayer interested in deferral would realize losses early and delay realization of gains, while one whose goal was averaging would realize losses in high income years and save his gains for periods of low income. ${ }^{88}$

\section{Policy Conclusions and the Current Code}

The analysis above indicates that capital losses should generally be deductible in full only if taxpayers who have both capital gains and losses are prevented from generating substantial deferral and averaging benefits and from exploiting the section 1201, 1202, and 1014 differentials. An acceptable system for capital loss treatment would thus have to meet the following five criteria.

(1) Capital losses should generally be deductible in full. Whether carryovers should be available depends on whether relief from the hardship caused by the annual accounting requirement is thought to be necessary.

88 Three other arguments for limiting the deductibility of capital losses are worth noting.

(1) Deductions for capital losses would provide a double tax exemption. This is part of a broader position that both gains and losses should be excluded from the income tax. Capital gains, on this theory, are now subject to double taxation because they reflect merely an increase in expected future earnings which will be taxed again when earned. By parity of reasoning, deduction of a capital loss would give xise to a double exemption if both the loss and the future reduction of income led to reduced taxes. I. Fisher \& H. FISHER, Constructive Income TAXation, A Proposal. For Reform 162 (1942). Of course, the double taxation (or exemption) argument assumes that the proper definition of income consists only of consumption, excluding changes in wealth, and fails if the assumption is unacceptable. See text at note 12 supra.

(2) Full deductibility would encourage speculation. G. Conway, The TAXation of CapITal GaINs, supra note 11, at 191; see Blum, supra note 20, at 254. There is no convincing empirical evidence to support this hypothesis. Moreover, even if it could be shown that more short-term than long-term trading would be stimulated by such a change, it is not at all clear that that would be detrimental to the economy or the fisc. See Somers, Reconsideration of the Capital Gains Tax, 13 NAT'x TAX J. 289, 301 (1960). Nonetheless, the legislative history of loss limitations reveals a long-standing effort to fashion restrictions for "speculators" as opposed to (long-term) "investors." See, e.g., 50 CoNG. REc. 3846 (remarks of Mr. Cummins), 3849 (remarks of Mr. Sterling) 513, (remarks of Mr. Williams); 61 Cong. REc. 6575-76 (1921); S. REP. No. 665, 72d Cong., 1st Sess. 17 (1932), 1939-1 CuM. BuLx. (Part 2) 508; S. Rrep. No. 558, 73d Cong., 2d Sess. 11-12 (1934), 1939-1 Gum. BulL. (Part 2) 595; S. Rep. No. 1631, 77th Cong., 2d Sess. 49-50 (1942); 97 CoNG. Rec. 11,740 (1951) (remarks of Mr. Humphrey).

(3) Full deduction of capital losses would aggravate stock market declines. See note 37 supra, and sources cited therein. 
(2) Taxpayers should not be able to deduct capital losses from ordinary income and benefit also from the alternative tax on equivalent gains under section 1201 .

(3) Taxpayers should not be able to deduct capital losses from ordinary income and also deduct 50 percent of equivalent net long-term capital gains from gross income under section 1202.

(4) Taxpayers should not be able to deduct capital losses from ordinary income while their transferees take capital assets with a date-ofdeath basis under section 1014 .

(5) Taxpayers with both unrealized gains and unrealized losses should not be able to achieve substantial additional tax savings through deferral or averaging by separating realization of their losses and gains into different years.

How do the current ${ }^{89}$ provisions of the Internal Revenue Code measure up? The Code allows a taxpayer to offset with capital losses up to $\$ 1,000$ of ordinary income annually, but it requires two dollars of longterm loss to offset a single dollar of ordinary income (with an unlimited carryover for both long-term and short-term losses ${ }^{20}$ ). The Code patently fails to meet the first criterion because of the $\$ 1,000$ ceiling on deductibility. Within that dollar limit, however, the third requirement is fulfilled insofar as long-term losses are involved. Thus, a taxpayer with $\$ 2,000$ in long-term gains and $\$ 2,000$ in long-term losses would obtain no differential tax advantage under existing law by including his gain

80 None of the earlier loss treatments enacted by Congress meet the policy criteria developed in the text. For a brief description of those provisions, see notes 1-3 supra. The nondeductibility rule of 1913 and the 1916 limitations of gains to losses obviously violate the first criterion, while the full deductibility rule of 1921 satisfies only the first. The maximum tax credit originally adopted in 1924 and reenacted in 1938 violates the first, third, and fourth criteria; it might have met the second if limited to taxpayers subject to the alternative tax, but even that much is doubtful given the changes made in the alternative tax by the Tax Reform Act of 1969. The step scales adopted after 1934 fail to meet any of the criteria; because of the diminishing percentage of recognition over time they would exacerbate the section 1202 differential for taxpayers able to realize losses before gains.

Although none of these provisions is any longer in force, it should not be thought that they are entirely discredited; occasional contemporary proposals for reform still call for at least a partial return to some regime of the past. See, e.g., A. CRest, Public Finance 304 (1960) (limitation of deductibility to gains); D. SMITH, FEDERAL TAX REFORM 150 (1961) (net losses should be offset against other income but with the tax savings limited to the tax rate that would have been applicable to a net gain); $c f$. L. KIMMEL, PosT-WAR TAX Pourcy AND BUSINESS EXPANSION 38 (1943); L. KIMMEL, supra note 26, at 124-25 (restrict loss offsets to "investment income"); S. Slichter, The American Economy: ITs Problems and ProsPECTs 84 (1948) (limitation of losses to " 50 percent of tax liability or to $\$ 100,000$ whichever is smaller'); Fagan, The Economics of Capital Gains Taxation, 32 NAT'L TAX Ass'N CoNF. Procerd. 113, 125 (1939) (any carryover should be of the "tax reduction value" of losses, defined as what a capital gains tax would have been had the loss been a gain in the year of realization).

90 INT. ReV. CODE OF 1954, §§ 1211-12. 
in one year pursuant to section 1202 ( $\$ 1,000$ inclusion) and realizing his loss in another ( $\$ 1,000$ deduction). The two-for-one offset, enacted as part of the Tax Reform Act of 1969, applies, however, not only to taxpayers with gains and losses, but also to taxpayers with capital losses only, limiting deductibility in cases outside the mandate of our third criterion. The second, fourth and fifth criteria are not met at all by the existing provisions. Only the denial of significant deductions to all taxpayers prevents selected investors from taking advantage of the section 1201 and 1014 differentials or splitting their gains and losses for deferral or averaging benefits.

The current Code thus meets only one of the five criteria identified above, and that one is met only in part. Part III of this article examines two proposals for reform of capital loss taxation. As will be seen, each of them is preferable to the present system when evaluated against the five criteria for appropriate tax treatment of capital losses.

\section{Two Proposals for REForm}

Each of two proposals for reform of capital loss taxation could satisfy all the policy criteria isolated above. Each, however, entails certain costs, and it is only by comparing their drawbacks that an intelligent choice between them can be made.

\section{A. Capital Loss Reserve}

Professor Martin David has suggested a novel method of treating capital losses. He has proposed that the present $\$ 1,000$ ceiling be increased to allow greater offsets against ordinary income, with losses so deducted to be cumulated in a capital loss reserve. Subsequent capital gains would be taxed as ordinary income up to the amount of the reserve balance, ${ }^{91}$ which would simultaneously be reduced by the amount of capital gains taxed as ordinary income. ${ }^{92}$

91 M. DAvid, supra note 4, at 140-42, 224.

92 A threshold nontheoretical difficulty with the David proposal arises in selecting the period within which the government could dispute a taxpayer's characterization of a loss as ordinary. If a taxpayer today claims a deduction for an ordinary loss which the government contends is a capital loss, the dispute should rightfully take place at once since the difference in tax treatment is immediate. If capital, as well as ordinary, losses are granted full deductions in the first instance, however, nothing may turn on the proper classification of a particular loss for many years, when a capital gain is realized. Under these conditions it may not be ideal either to force the government to make its claim at once (when nothing turns on it) or to permit the government to assert that a capital gain should be taxed as ordinary income because a particular loss had been erroneousiy characterized as ordinary years before. Perhaps a practical accommodation would be to designate a certain period, such as ten years, after which the government could no longer dispute a taxpayer's characterization of a particular loss as capital or ordinary. 
As originally proposed, the reserve plan would not embody a general rule of full deductibility because some dollar ceiling on loss deductions would be retained. That divergence from the first policy criterion urged above could easily be remedied, however, by eliminating the ceiling as well as the two-for-one offset of long-term losses against ordinary income enacted in 1969. By its own terms, the David proposal fulfills our second and third requirements: taxation of subsequent capital gains as ordinary income necessarily eliminates the section 1201 and 1202 differentials.93 Later net gains would, in effect, be retroactively netted with prior net losses.

Although the original proposal is ambiguous on this point, the applicable policy considerations suggest that while net losses, whether long-term or short-term, should be taken into the reserve computation, only net long-term gain should operate to reduce the loss reserve balance. As we have seen, ${ }^{94}$ short-term losses must be included in the reserve to prevent their netting with long-term gain from creating a differential. Net short-term capital gain, on the other hand, if it exceeds net long-term capital loss, should not reduce the reserve balance because the excess would receive ordinary income treatment in any event.

The David proposal makes no attempt to eliminate the section 1014 differential, our fourth requirement. Indeed, Professor David would retain a dollar ceiling on capital losses precisely because capital gains can escape taxation completely at death. ${ }^{95}$ That accommodation is, of course, inappropriate under the view espoused here because taxpayers who have only losses, or losses substantially in excess of gains, are penalized during their lifetimes by the denial of full deductibility without any corresponding benefit at death.

Nevertheless, by an extension of its own logic, the reserve plan can be modified to eliminate the section 1014 differential by taxing at death unrealized net capital gains as ordinary income up to the amount of the reserve balance at death. The taxpayer's devisees or heirs would take their property with a date-of-death basis, as under current law. Full taxation of unrealized net gain at death, to the extent of prior net losses reserved, would thus eliminate the section 1014 differential in the same way that full taxation of gains during life, to the extent of prior losses, would eliminate the section 1201 and 1202 differentials. Furthermore, the problems of administering this system would be no different

93 Constructive realization would occur when an appreciated capital asset was given away by a taxpayer with a positive loss reserve, in order to prevent his donee from realizing the gain at a preferential rate. M. DAvm, supra note 4 , at 224.

04 See text at page 317.

95 M. Davm, supra note 4, at 141 n.30. 
from those already faced for purposes of federal income and estate taxation-determination of basis, valuation of property passed at death, and liquidity to pay the tax.

Because any dilution of the exclusionary effect of section 1014 on unrealized gain at death may at first be anathema to many taxpayers, it is important to observe that under this proposal gains would be constructively realized at death only to the extent of the capital loss reserve at death. Thus, any taxpayer whose capital gains would be taxed at death as ordinary income would already have deducted equivalent capital losses from ordinary income. The present exclusion of gains from income at death, coupled with exclusion of almost all net losses during a taxpayer's lifetime, would be replaced by full deduction of losses during life and full inclusion of net gains at death only to the extent that lifetime net losses exceeded lifetime net gains. It would seem that only taxpayers for whom the present $\$ 1,000$ offset against ordinary income provides deductibility sufficient to absorb all their capital losses would prefer the present formulation. ${ }^{96}$

The most troubling aspect of the capital reserve plan is its potential for use as a deferral or averaging device. Although the taxation of gains as ordinary income to the extent of prior net deductions would make the net lifetime addition to, or reduction of, taxable income from capital asset transactions equal to what it would have been had gains and losses been netted before inclusion and deduction, the taxpayer would still benefit under the plan from early deduction of losses and deferred realization of gains. A direct method of eliminating the additional deferral benefits accruing from failure to net gains and losses would be to tax imputed interest on the tax liability deferred. For a taxpayer who realizes gains and losses variously over a period of years, it would be exceedingly difficult to calculate the precise amount of deferral benefit attributable to any given loss deduction and realization of gain. An approximation could be made, however, by taxing the imputed interest on capital gains that had been taxed as ordinary income.

Unfortunately, Congress has not been willing to impute interest to other forms of unrealized appreciation, and there is little reason to believe it would be willing to do so in this case. Moreover, the adoption of such a plan to eliminate the benefit of deferral under full deductibility would create its own problems. An imputed interest rate or rates

96 If it were thought desirable to leave the treatment of such taxpayers unchanged, $\$ 1,000$ per annum could be exempted from the reserve, although it would be inconsistent with the basic theory of the proposal to do so. 
would have to be selected, but no administratively feasible system could hope to offset the actual benefits of deferral to taxpayers experiencing different rates of return on their deferred liabilities. If a long-held asset had appreciated only shortly before being sold, would interest be imputed from the time it was purchased if the loss reserve had been outstanding since that time? To tax imputed interest for the full period seems unfair since the appreciation is more recent, but to defer imputation of interest until the actual appreciation occurs would require an annual valuation of capital assets, an administrative nightmare that the tax on only realized gain currently avoids.

Even if the problems in eliminating the deferral benefits inherent in the loss reserve plan were overcome, there would still be no inhibition against a taxpayer's using losses and gains to average his income except in the sense that possible later taxation of imputed interest might introduce some uncertainties into the planning process. The only way to eliminate fully that type of "avoidance" would be to require the taxpayer to recompute his taxes as if he had not earlier "averaged" (by splitting gains and losses), a result which, because of its administrative complexity and the departure from the annual accounting principle it would entail, should be rejected. The availability of a feasible method of reducing deferral advantages would probably be enough, however, to make the reserve plan theoretically acceptable under our fifth policy criterion, since the benefits of averaging are too directly tied to the realization principle to be completely eliminated from an otherwise attractive scheme. ${ }^{97}$

Although the capital loss reserve proposal can thus be modified to meet all five policy goals suggested above, it should be noted that the plan may entail a significant cost, as David acknowledged, ${ }^{98}$ in the form of a heightened "lock-in effect." The supposed lock-in effect inheres in

97 Another difficulty with the reserve proposal is its inability to eliminate taxation differentials where gains substantially precede losses. Consider a taxpayer with $\$ 10,000$ in unrealized long-term gains and $\$ 10,000$ in unrealized long-term losses. If he were to realize his gains before his losses, he would first include only $\$ 5,000$ in taxable income but later deduct $\$ 10,000$ from ordinary income with impunity under the reserve plan. Of course, a mechanism could be designed to limit losses in cases of prior gains-the mirror image of the reserve device-but the complexities of that solution are frightening. There is probably no need for such a device under the modified reserve because the excess loss would be eliminated when the taxpayer next realized gains, or at death if gains remained unrealized. The taxpayers who cause concern in this area are likely to have additional gains at a later date; only taxpayers with losses preceded, but not followed, by actually or constructively realized gains could take advantage of rate or inclusion differentials. In any event, the remaining deferral benefits of postponing gains while realizing losses would provide a disincentive to early realization of gains and delayed realization of losses.

98 M. DAVID, supra note 4 , at $142-43$. 
any taxing of gain on capital assets: a taxpayer whose investment has appreciated in value will, it is argued, be reluctant to realize his gain because the after-tax proceeds could only be reinvested in an asset of lesser value. Hence investors are said to be locked into their appreciated investments by the tax-discouraged from profit-taking-contributing to a decreased liquidity in the capital markets.99

The original adoption of preferential rates for capital gains in 1921 was based in part on the lock-in effect of ordinary income treatment. ${ }^{100}$ It might be argued that to reinstate full taxation of gains for some taxpayers, as under the capital loss reserve system, would be to return pro tanto to the pre-1921 system. For example, a taxpayer in the 50 percent bracket who has a reserve balance of $\$ 1,000$ (due to an earlier capital loss of that amount) and could later, in a year without capital losses, realize a capital gain of $\$ 1,000$ would, according to this theory, be reluctant to realize his gain because he would have only $\$ 500$ of gain to reinvest after taxes. If taxable interest were imputed to his gain, he would have even less than $\$ 500$ of gain to reinvest.

The lock-in theory has been much criticized, ${ }^{101}$ and what little empirical evidence there is tends to support the view that, with certain exceptions not here relevant, the lock-in effect has not significantly impaired the transferability of assets. ${ }^{102}$ At the least, the existence of the

99 See, e.g., Brown, The Locked-in Problem, in U.S. Congress, JOINT COMM. ON TFE ECONOMIC REPORT, FEDERAL TAX POLICY FOR ECONOMTC GROWTH AND STABITITY 367 (1955); Klem, supra note 24; Schram, supra note 32; Somers, supra note 88; Somers, An Economic Analysis of the Gapital Gains Tax, 1 NAT'L TAX J. 226 (1948); Wallich, Taxation of Gapital Gains in Light of Recent Economic Developments, 18 NAT'L TAX J. 133, 134 (1965).

100 H.R. REP. No. 350, 67th Cong., 1st Sess. 10-11 (1921), 1939-1 Cum. Bur.. (Part 2) 176; S. Rep. No. 275, 67th Cong., 1st Sess. 12-13 (1921), 1939-1 Cum. Burc. (Part 2) 189-90. Congress has since been urged to reduce the capital gains tax on the theory that the elimination of the lock-in will encourage realization to such an extent that more revenue will be raised at the lower rate. Research commissioned by the New York Stock Exchange concluded that reducing the maximum alternative tax to 12.5 percent would increase fivefold the amount of appreciation "unlocked" and subject to capital gains taxation. Sprinkel \& West, Effects of Capital Gain Taxes on Investment Decisions, 35 J. Business 122 \& n.I (1962); cf. M. DAVD, supra note 4, at 200. But see L. SELTZER, supra note 4, at 206-09; Fredland et al., Six Month Holding Period for Capital Gains-Empirical Analysis of Its Effect on Timing of Gains, 21 NAT'L Tax J. 467-78 (1968); Hinrichs, An Empirical Measure of Investor's Response to Differentials in Capital Gains Tax Rates Among Income Groups, 16 NAT'L TAX J. 224, 228 (1963).

101 For a sampling of the theoretical attack, see M. DAvid, supra note 4, 225-26; Heller, supra note 37, at 394; Batt, The Gray Fleece of the Grimson Cat: A Primer of Tax Nonsense, 51 Kx. L.J. 187, 204 (1962); Beazer, Expected Income Changes and the Lock in Effect of the Capital Gains Tax, 19 NAT'L TAX J. 308, 314 (1966); Blum, supra note 20, at 258; Kendrick, The Tax on Capital Net Gains, 19 AM. EcoN. Rev. 648, 649 (1929); Richman, Reconsideration of the Gapital Gains Tax-A Comment, 14 NAT'L TAx J. 402, 403 (1961); and Richman, supra note 37.

102 For conclusions based on empirical data, see R. BarLow et al., supra note 65, at 
lock-in effect seems insufficiently established to bar, by itself, the adoption of the proposed reserve plan. If it is a significant phenomenon, however, adoption of the reserve plan would surely be problematic.

A third possibility-that whatever the theoretical validity of the effect, it has a definite impact on investor psychology ${ }^{103}$ - is more easily reconciled with the proposal, which could be recast in the form of a recapture plan. ${ }^{104}$ Losses would be fully deductible but when gains were later taxed at preferential rates, whether in life or at death, prior net losses would be recaptured to have the effect of retroactively netting gains and losses. This scheme would always have precisely the same result as the modified David plan. ${ }^{105}$ It would also have the psychologi-

119-20; J. Butters, L. Thompson, \& L. Bollinger, supra note 30, at 346; T. SANDers, EFFECTS OF TAXATION ON EXECUTIVES 214 (1951); L. SELTZER, supra note 4, at 156-80; Castruccio, Becoming More Inevitable? Death and Taxes . . And Taxes, I7 U.C.L.A.L. REv. 459, 468-76 (1970). See also R. Goode, supra note 22, at 213.

103 A substantial number of investors seem to believe in the importance of the effect. See Heller, supra note 37, at 386; Twentieth Century Fund, The Securuty Markets 347 (1935). For attempts to provide the investor with a rational measure of the lock-in effect, see Holt \& Shelton, The Lock-In Effect of the Capital Gains Tax, 15 NAT'L TAX J. 337 (1962); Holt \& Shelton, The Implications of the Capital Gains Tax for Investment Decisions, $16 \mathrm{~J}$. FINANCE 559 (1961); Sprinkel \& West, supra note 100.

104 The recapture plan would provide: (l) All net capital losses would be fully deductible from ordinary income, with an excess loss carryover if it is thought to be desirable. (2) Fifty percent of such deductions would be recaptured as ordinary income up to 50 percent of any excess of net long-term capital gain over net short-term capital loss in later years. Net long-term gain would receive existing preferential treatment except that the alternative tax would be unavailable to the extent of losses recaptured in any given year. (3) All prior net loss deductions not recaptured under (2) would be recaptured at death to the extent of unrealized net capital gains at death. As under current law, the unrealized gains would then go untaxed and appreciated assets would receive the stepped-up basis of section 1014. (4) Deferral benefits would be eliminated by imputing taxable interest, as under the reserve plan, to net loss deductions recaptured under (2) or (3).

105 In a year of net capital loss, the loss would be fully deductible under both the reserve and recapture schemes, creating in each case the same reduction in tax liability. At death, the reserve plan would include unrealized net capital gain, up to the balance in the capital loss reserve, in taxable income, while the recapture plan would include accumulated unrecaptured capital losses, to the extent of unrealized net capital gainprecisely the same figure. Similarly, under both proposals the alternative tax would be unavailable to the extent of past net losses.

That the proposals will yield identical results without the alternative tax for years in which the taxpayer realizes an excess of net long-term capital gain over net short-term capital loss is also true, but less obvious. If $K G$ is the excess of net long-term capital gain over net short-term capital loss in such a year, and $\mathrm{KL}$ is the amount of net long-term capital loss previously deducted from income and not yet set off against gains, the amount of additional taxable income due to capital gains in such a year under the reserve plan is:

$$
\mathrm{KG} \text { (up to } \mathrm{KL})+[.5(\mathrm{KG}-\mathrm{KL}) \text { iff. } \mathrm{KG}>\mathrm{KL}]
$$

The amount under the recapture proposal is:

$$
.5 \mathrm{KL} \text { (up to } .5 \mathrm{KG})+.5 \mathrm{KG} \text {. }
$$

If [a] and [b] must be equal, then the result under the two proposals will always [b] identical. Assume first that $\mathrm{KG}$ is greater than $\mathrm{KC}$. Then [a] becomes: 
cal advantage of focusing taxpayer attention in the year of later adjustment on the prior loss rather than the current gain.

In summary, the capital loss reserve proposal suggested by Professor David could, with modifications and extensions, satisfy all our policy goals for capital loss taxation. There are, however, defects in the reserve plan-the possibility of increased lock-in and, more importantly, the problems generated by introducing an interest factor to eliminate deferral benefits-that make preferable an alternative system that meets our goals without engendering these problems. One such plan is proposed below.

\section{B. Partially Deferred Deduction}

The two-for-one offset feature of current capital loss treatment provides the nucleus of the plan for partially deferred deduction of net losses. As explained above, that offset now eliminates the section 1202 differential for an excess of net long-term loss over net short-term gain. By extension, reducing ordinary income by 50 percent of all net capital losses would eliminate the section 1202 differential in all cases. Taxpayers would deduct their net losses from ordinary income without a dollar ceiling, but because it would take two dollars of net loss to offset a dollar of ordinary income there would be no advantage under section 1202 to realizing gains and losses in separate years.

Because taxpayers could thus effectively offset only 50 percent of their net losses against ordinary income in the year of loss realization, the remaining 50 percent would have to be deductible at some other time if we are to have a general rule of full deductibility. The additional deduction should be permitted after some fixed period, such as five years, but only to the extent the taxpayer has not benefited from section 12.02 in the interim.

Like the loss reserve, this proposal would, in effect, net gains and losses over a period of years. The essential difference is that the partially deferred deduction scheme delays half the taxpayer's net loss

Making the same assumption, $[\mathrm{b}]$ becomes:

$$
\mathrm{KL}+.5 \mathrm{KG}-.5 \mathrm{KL}=.5 \mathrm{KG}+.5 \mathrm{KL} .
$$

$$
.5 \mathrm{KL}+.5 \mathrm{KG} \text {. }
$$

When KG is less than KL, [a] will be:

$$
\text { KG }
$$

Likewise, [b] will be:

$$
.5 \mathrm{KG}+.5 \mathrm{KG}=\mathrm{KG} \text {. }
$$

Finally, where $\mathrm{KG}=\mathrm{KL}$, tax liability under the reserve is:

Under the recapture proposal: KG or KL. 
deduction instead of the government's tax on net gains, thus reducing substantially the deferral benefits of full deductibility. In addition, withholding 50 percent of each loss deduction for several years would make averaging considerably more difficult; the level of a taxpayer's income is generally indeterminate more than a few years in advance.

The corresponding costs of the deferred deduction plan are two. First, whatever benefits are thought to flow from full deductibility would be partially delayed. Second, a taxpayer could still achieve some deferral benefit and perhaps take advantage of the sections 1201 and 1202 differential by deducting losses early and delaying realization of gains until after the end of the deferred loss period.

The period of deferral should be designed to minimize the joint product of these costs. It should be long enough to make significant tax planning, such as currently deducting losses and putting gains off until after the deferral period, impractical; but it should not be so long as to dilute significantly the benefits of full deductibility.

Technically, the deferred deduction plan could be implemented on the basis of a moving period of, say, five years. Accounts would be kept of net losses deducted more than five years previously (representing the deferred half of each loss) and gains realized in the interim subject to section 1202. The two accounts would be netted annually and the excess net loss deducted from ordinary income. ${ }^{106}$ The table on page 324 illustrates how the system would operate in a specific example.

The taxpayer in the example given in the table suffers a net capital loss of $\$ 20,000$ over the ten-year period. The net losses in years one, two, and five give rise to immediate 50 percent deductions, while 50 percent of the gains in years three, four, and ten are immediately taken into taxable income, creating a net immediate deduction of $\$ 10,000$ over ten years. The deferred losses of years one, two, and five are available in years six, seven, and ten. Because of intervening section 1202 gains, however, the loss deferred from year one is wholly offset in year six, yielding no additional deduction; instead the section 1202 gain account is reduced from $\$ 15,000$ to $\$ 10,000$. Similarly, in year seven, the $\$ 15,000$ net loss deferred from year two first goes to offset the remaining $\$ 10,000$ of intervening gain and then to yield a deduction of $\$ 5,000$. The $\$ 10,000$ loss deferred from year five to year ten produces a deferred deduction of $\$ 5,000$ after netting with the $\$ 5,000$ of gain deducted under section 1202 in that year. Thus, with all accounts cleared by the transactions in

108 At death, a deduction would be permitted for the deferred half of losses deducted less than five years previously, since the section 1202 differential would no longer be available. 
Partially Deferred Deduction Accounting Using a Five-Year Deferral Period

\begin{tabular}{|c|c|c|c|c|c|}
\hline Year & $\begin{array}{c}\text { A } \\
\text { Net capital loss } \\
(-) \text { or excess of } \\
\text { net long-term } \\
\text { capital gain } \\
\text { over net } \\
\text { short-term } \\
\text { capital loss (t) }\end{array}$ & $\begin{array}{c}\text { B } \\
\text { Current net } \\
\text { deduction } \\
\text { from, or } \\
\text { inclusion } \\
\text { in taxable } \\
\text { income }\end{array}$ & $\begin{array}{c}\text { C } \\
\text { Net loss } \\
\text { account } \\
\text { (cumulative) }\end{array}$ & $\begin{array}{c}\mathrm{D} \\
\text { Net section } \\
\text { 1202 gain } \\
\text { account } \\
\text { (cumulative) }\end{array}$ & $\begin{array}{c}E \\
\text { Deferred } \\
\text { deduction } \\
(C-D)\end{array}$ \\
\hline 1 & $\$-10,000$ & $\$-5,000$ & 0 & 0 & $\$$ \\
\hline 2 & $-30,000$ & $-15,000$ & 0 & 0 & 0 \\
\hline 3 & $+10,000$ & $+5,000$ & 0 & 5,000 & 0 \\
\hline 4 & $+20,000$ & $+10,000$ & 0 & 15,000 & 0 \\
\hline $\boldsymbol{5}$ & $-2,0,000$ & $-10,000$ & 0 & 15,000 & 0 \\
\hline 6 & 0 & 0 & 5,000 & 15,000 & 0 \\
\hline 7 & 0 & 0 & 15,000 & 10,000 & 5,000 \\
\hline 8 & 0 & 0 & 0 & 0 & 0 \\
\hline 9 & 0 & 0 & 0 & 0 & 0 \\
\hline 10 & $+10,000$ & $+5,000$ & 10,000 & 5,000 & 5,000 \\
\hline $\begin{array}{l}\text { Net gain } \\
\text { or loss } \\
\text { over ten } \\
\text { years }\end{array}$ & $\$-20,000$ & $\$-10,000$ & & 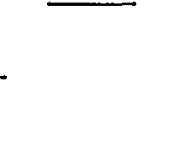 & $\$-10,000$ \\
\hline
\end{tabular}

Column A represents the annual result of netting gains and losses, column $B$ the resulting current net inclusion ( 50 percent of an excess of net long-term capital gain over net short-term capital loss) in, or deduction (50 percent of net capital loss) from, taxable income. Column $\mathrm{C}$ cumulates the undeducted 50 percent of net capital losses realized five years earlier, while column $\mathbf{D}$ cumulates the $\mathbf{5 0}$ percent of gains deducted under section 1202 and not subsequently offset by deferred net losses. The amounts in column $\mathbf{E}$, the remainders when column $D$ is subtracted from column $G$, would be currently deductible (hence the negative value of the column $\mathrm{E}$ total).

year ten, the deferred deductions yield $\$ 10,000$ of additional offsets against ordinary income.

As outlined above, the deferred deduction scheme would make capital losses generally deductible in full, prevent taxpayers from using the section 1202 differential, and not enable those with unrealized gains and losses to further minimize their taxes through undue deferral or averaging techniques. In addition, the section 1201 differential could be eliminated by barring use of the alternative tax for gains up to the amount of realized losses during the deferral period.

As was suggested with regard to the reserve plan, the section 1014 differential could be dealt with by taxing net gains at death as ordinary income up to the excess of lifetime losses over lifetime gains or, put differently, by recapturing prior net losses up to the amount of net unrealized gains at death. Some deferral benefits would still be possible: a taxpayer with gains and losses might realize the losses, deduct them 
in full within five years, and yet postpone realizing his gains until death, when they will be taxed as ordinary income only to the extent of the earlier net losses. Such limited deferral benefits are probably necessary if full deductibility is to be achieved in a system that steps-up basis at death; the only sure way to eliminate them would be to hold all net losses in abeyance until death in order to see then whether there were gains to be netted retroactively. That scheme, however, would destroy the very benefits thought to make full loss deductibility worthwhile in the first place.

In summary, the partially deferred deduction plan for effectuating the appropriate tax treatment of capital losses would thus have the following features. First, net capital losses would be deductible from ordinary income, but a dollar of loss would offset only fifty cents of ordinary income. In the event of insufficient ordinary income, net losses might be carried forward indefinitely if the annual accounting principle is thought to be less important than relief in cases of hardship. Second, net loss deductions taken more than five years previously would be cumulated in a net loss account that would be netted annually with an account of intervening section 1202 gains. The excess of losses, if any, would be deductible from ordinary income. If the excess exceeded ordinary income, provision might be made for a limited carryback (since the losses arose in the past) and an indefinite carryforward. Third, the alternative tax would not be available for gains to the extent of losses realized during the deferral period. Finally, net gains would be taxed at death as ordinary income to the extent that lifetime losses exceeded lifetime gains. Alternatively, net gains would be untaxed at death, but excess prior net losses would be recaptured at ordinary income rates. Transferees would take their property with a date-of-death basis in either event.

\section{Conglusion}

The history of capital loss treatment under the federal income tax law has been kaleidoscopic. To the extent that a consensus has gradually emerged, traditional wisdom has it that partial taxation of capital gains should lead to limited deductibility of capital losses. Yet, on inspection, only the possibility of tax avoidance, either through differentials between the taxation of capital gains and deductions from ordinary income or through averaging and deferral where the taxpayer controls realization, supports that conclusion.

While none of the previously suggested or enacted tax treatments of capital losses can effectuate the relevant policy goal-full deductibility without the possibility of taxation differentials or averaging and deferral 
benefits-Professor David's capital loss reserve and the Tax Reform Act's 50 percent deduction provide the foundations of alternative proposals for achieving that end. Unless taxable interest on deferred taxes can practically be imputed, the proposal for delaying $\mathbf{5 0}$ percent of loss deductions for a short period is the preferable one. 